\title{
Neznámý český Almanach Erharda Etzlauba na rok 1527 objevený v poznaňské univerzitní knihovně
}

\author{
JAKUB EUKASZEWSKI
}

$\mathrm{V}$

průběhu katalogizace tisků 16. století ve sbírkách poznaňské univerzitní knihovny jsem narazil na vydání díla Eusebia z Kaisarei Acutores bistoriae ecclesiasticae (Basel, Johannes Froben VIII 1523. $2^{\circ}$; sign. univerzitní knihovny SD 3707III). ${ }^{1}$ Po důkladnějším prozkoumání jsem zjistil, že zadní př́deští ${ }^{2}$ vazby tohoto tisku tvoři fragment neznámého českojazyčného nástěnného kalendáře na rok 1527 . $^{3}$

Ukázalo se, že autorem sejmutého fragmentu kalendáře byl proslulý norimberský kartograf, astronom, lékař a konstruktér astronomických přístrojů Erhard Etzlaub (1462-1532). ${ }^{4}$ Etzlaub byl rovněž autorem jedenácti nám dosud známých vydání nástěnných kalendářů (almanachů). Informace o dochovaných exemplářich uspořádal Fritz Schnelbögl: chronologicky jsou to kalendáře na roky $1515^{5}$ (německý); 1517 (český); 1518 (latinsko-německý); 1520, 1521, 1525, 1528, 1529, 1530, 1532 (německé); 1531 (latinský). ${ }^{6}$

1 VD16 E 4273.

2 Kalendár̆, nalepený potištěnou stranou na desky, vyjmula mgr Renata Kosiniec z Pracowni Restauracji Książki Biblioteki Uniwersyteckiej w Poznaniu, za což jí na tomto místě velmi děkuji.

3 Zásadní informace a reference na literaturu o českých nástěnných kalendárích sesbíral Petr Voit v díle Encyklopedie knihy. Starš knibtisk a prübuzné obory mezi polovinou 15. a poúătkem 19. stoleti, Praha 2008, s. 595, heslo Minuce.

4 Otto MAULL, Neue Deutsche Biographie, Bd. 4, 1959, s. 669, heslo Etzlaub Erhard; Herbert KRÜGER, Des Nürnberger Meisters Erhard Etzlaub älteste Straßenkarten von Deutschland, Jahrbuch für fränkische Landesforschung, Bd. 18, 1958, s. 1-407; Fritz SCHNELBÖGL, Life and Work of the Nuremberg Cartographer Erhard Etzlaub (†1532), Imago Mundi 20, 1966, s. 11-26. (totéž v německém jazyce: Leben und Werk des Nürnberger Kartographen Erhard Etzlaub (gest. 1532), Mitteilungen des Vereins für Geschichte der Stadt Nürnberg, Bd. 57, 1970, s. 216-231); Klaus MATTHÄUS, Zur Geschichte des Nürnberger Kalenderwesens. Die Entwicklung der in Nürnberg gedruckten Jahreskalender in Buchform, Archio für Geschichte des Buchwesens, Bd. 9, 1968, Lieferung 3-5, s. 1018-1020; Nine Robijntje MIEDEMA, Erhard Etzlaubs Karten. Ein Beitrag zur Geschichte der mittelalterlichen Kartographie und des Einblattdrucks, Gutenberg Jahrbuch 71, 1996, s. 99-125; P. VOIT, Encyklopedie ..., pozn. 3, s. 251, heslo Etzlaub, Erhard.

5 F. SCHNELBÖGL, Leben ..., pozn. 4, s. 218, pozn. 9.

${ }^{6}$ F. SCHNELBÖGL, Leben ..., pozn. 4, s. 230, pozn. 41. 


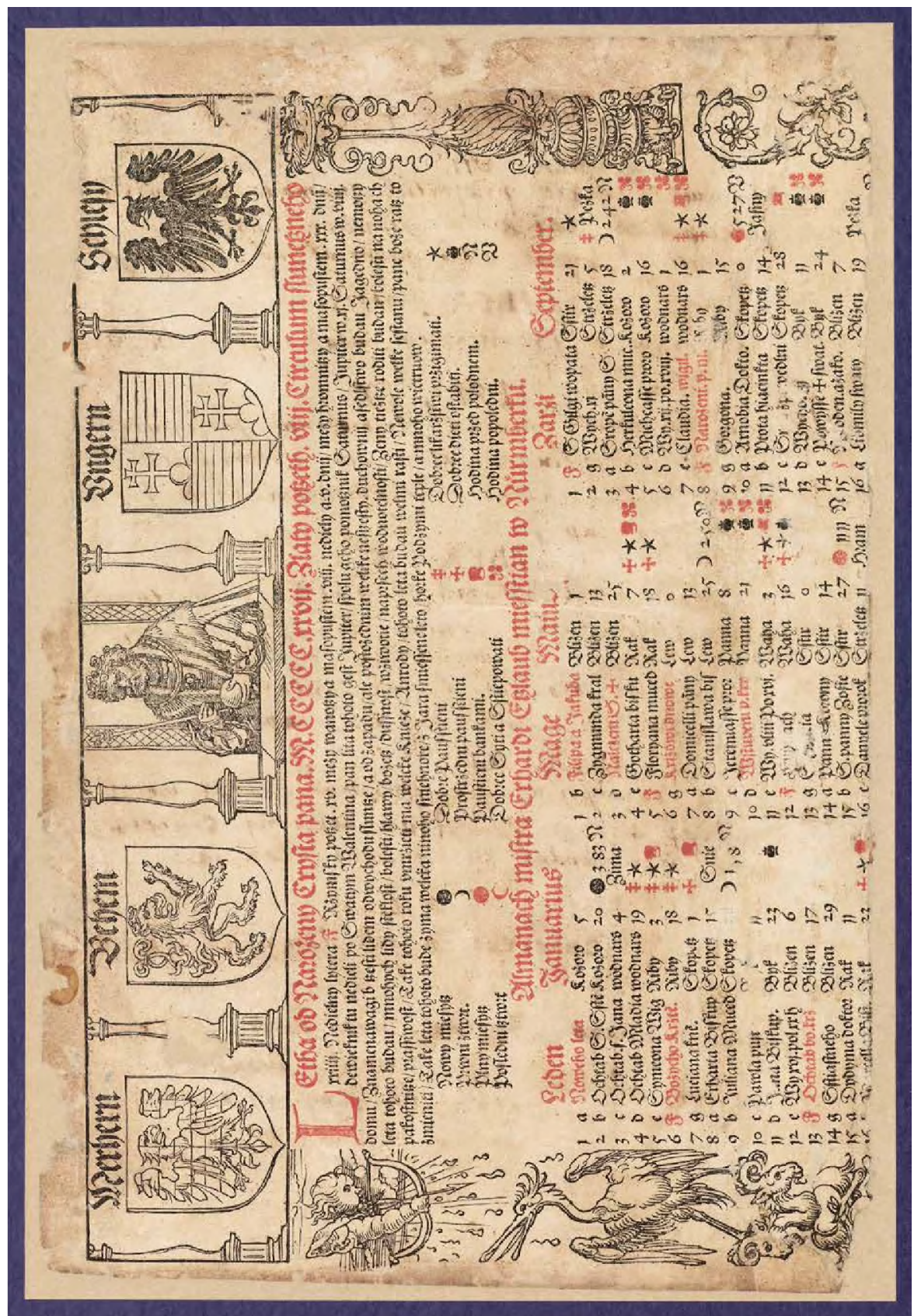

Obr. 1: Almanach mistra Erhardi Etzlaub miesstian w Nürmberku, [Nürnberg, Hieronymus Andreae 1526/1527], 1 fol. $(294 \times 197$ mm). Biblioteka Uniwersytecka w Poznaniu, sign. SD $915911 \mathrm{II}$. 
Objevený exemplár je nekompletní, zachovala se jeho horní část a fragmenty (po 16 dnech) měsícủ ledna, května a záríi. Chybí tedy více než tři čtvrtiny textu.

Kalendář byl sestaven pro území českého a uherského království. Naznačuje to velká dřevořezová titulní ilustrace v horní části listu, jejiž střed tvoři poprsí trůnícího vládce, po jehož bocích jsou umístěny erby Cech, Uher, Moravy a Slezska (obr. 1). Obsah tohoto nástěnného kalendáře je uspořádán obvyklým způsobem, opakuje schéma jiných tehdejších almanachů. $V$ úvodní, narační části jsou zahrnuty nejvýznamnější informace: o zlatém řezu, výpočtu slunečního kruhu a nedělních písmenech. Následují popisy intervalů dělících Boži hod vánoční od masopustní neděle $(\text { Esto mißhi })^{7}$ a období od svátku Uvedení Páně do chrámu až po tutéž neděli. Kromě toho se dozvídáme, že devátá neděle před Velikonocemi (Septuagesima - devitník) následovala po svátku sv. Valentýna. Následuje Etzlaubova astronomická prognóza na rok 1527. Níže jsou uvedeny vysvětlivky astronomických a lékařských symbolů použitých v kalendáři.

Kde by tento almanach vytištěn? K identifikaci dílny nás navádí zachované zbytky groteskových dřevořezových ozdůbek, které rámují text Almanachu a tiskové písmo. Rám se skládá nejméně ze tří dřevořezových štočkủ, nepochybně norimberského původu, vycházejících z dürerovské školy. ${ }^{8}$ Zleva je to fragmentárně zachovaný sloup zakončený dvěma kozími hlavami, na kterých stojí volavka a nad ní amorek. ${ }^{9}$ Naproti tomu z pravé strany se nachází kandelábrový sloup na třech lvích maskách a fragment rostlinné rozviliny, která je s určitostí pozůstatkem po charakteristickém ornamentu představujícím hlavu s arabeskovou dekorací. ${ }^{10}$ Dvě ozdobné lišty na pravé straně kalendáře lze nalézt na titulních stranách dvou anonymních tiskủ, které byly dříve přisuzovány würzburské tiskárně Balthasara Müllera: Johann Eberlin von Günzburg, Ein getrewe warnung ..., [S.1., s.t.n., s.a.], $4^{011}$ a Auszug eines briefes, [S.1., s.t.n.,

\footnotetext{
7 Podle výpočtu v kalendárí vycházelo toto období na 8 týdnů a 5 dní. Je to sazečská chyba (viii místo viiij), nebot tento interval správně činil 9 týdnů a 5 dní.

8 Heinrich RÖTTINGER, Dürers Doppelgänger, Studien zur deutschen Kunstgeschichte, 1926, Heft 235, s. 18-23.

9 H. RÖTTINGER, Dürers Doppelgänger ..., pozn. 8, Fig. 30 (levá lišta).

${ }^{10}$ H. RÖTTINGER, Dürers Doppelgänger ..., pozn. 8, Fig. 29 (levá a horní lišta).

11 VD 16 E127; Karl SCHOTTENLOHER, Balthasar Müller in Würzburg. (Fränkische Druckerein der Reformationszeit 2), Zentralblatt für Bibliotbekswesen 38, 1911, nr. 5 , s. $64-72$.
} 
post III 1526], 4‥12 Avšak Gisela Möncke přesvědčivě dokázala, že tyto dvě publikace pochází z norimberské dílny Hieronyma Andreae. ${ }^{13}$ Text kalendáře byl vy tištěn dvěma stupni fraktury, taktéž z tiskárny $\mathrm{H}$. Andreae (fraktura „Neudörfer-Andreae“ tzv. „dürerovská“). ${ }^{14}$

Zde je třeba zdůraznit, že výše popsaný dekor a tiskové písmo užíval později, od roku 1527, Balthasar Müller ${ }^{15}$ ve Würzburgu, kde tiskl také Etzlaubovy kalendáře. ${ }^{16}$ Zatímco zde popisovaný Almanach vyšel pravděpodobně nejpozději ke konci roku 1526, tedy ještě v Norimberku. Což není koneckonců nic divného, nebot Norimberk byl tehdy nejvýznamnējším nečeským vydavatelským centrem, které produkovalo českojazyčné knihy. ${ }^{17}$ Odtud také pochází Etzlaubův jediný dosud známý českojazyčný nástěnný kalendá ̌́ na rok 1517, který vyšel $\mathrm{z}$ dílny Adama Dyona. ${ }^{18}$

Almanach se bezpochyby nacházel v Cechách. Svědčí o tom skutečnost, že byl využit pro prŕdeští svazku, jehož vazba byla s největší pravděpodobností realizována v pražské knihvazárně Mistra Práv českých kolem roku $1530 .{ }^{19}$ Takto svázané dílo Eusebia z Kaisarei (dedikantem byl

12 VD 16 A4423; K. SCHOTTENLOHER, Balthasar Müller ..., pozn. 11, nr. 6, 64-72; H. RÖTTINGER, Dürers Doppelgänger ..., pozn. 8, Fig. 29 (reprodukce titulní strany).

13 Gisela MÖNCKE, Zum Würzburger Buchdruck in der ersten Hälte des 16. Jahrhunderts: Johann Lobmeyer - Balthasar Müller - Melchior Bopp, Archiv für Gescbichte des Buchwesens, 2008, Band 62, s. 155-157 a s. 162 .

${ }^{14}$ Ernst CROUS - Joachim KIRCHNER, Die gotischen Schriftarten, Leipzig 1926, podobizny: Taff. 63, Abb. 126 a také Taff. 64, Abb. 131. Je to velmi brzký případ užití fraktury pro český jazyk (ale samožrejmě bez diakritických znamének), srov. P. VOIT, Tiskové písmo Cech a Moravy první poloviny 16. století, Bibliotheca Strahoviensis 10, 2011, s. 155.

15 G. MÖNCKE, Zum Würzburger Buchdruck..., pozn. 13, s. 162, (Leisten 1-2 a také Fraktura Typ 4). Zde je vhodné poznamenat, že výzdobu ve formě sloupu (Leiste 2) původně završovala mužská postava $v$ podřepu s vystrčeným pozadím a celé vyobrazení bylo zarámováno. Podle G. Möncke to měl být würzburský tiskař Balthasar Müller, jenž převzal část typografického vybavení $H$. Andreae, který urážlivého šaška ze sloupu, stejně jako orámování odstranil (s. 157). Zde popisovaný kalendář naznačuje, že $\mathrm{k}$ tomu došlo ještě v Norimberku u Hieronima Andreae.

16 G. MÖNCKE, Zum Würzburger Buchdruck..., pozn. 13, s. 166 nr. 21; s. 168, nr. 27; s. 171 nr. 39 ; s. 172 nr. 48.

17 P. VOIT, Role Norimberku při utváření české a moravské knižní kultury první poloviny 16. století, Documenta Pragensia 29, 2010, s. 389-390.

18 P. VOIT, Role Norimberku ..., pozn. 17, s. 406, 439; Petr VOIT, Český knibtisk mezi pozdni gotikou a renesanci II, tiskaři pro obrozeni národa 1498-1547, Praha 2017, s. 95; Knibopis ceskych a slowenských tiskỉ od doby nejstarsí aź do konce 18. stoleti, Praha 1946, s. 167-168, K02383.

19 Svědčí o tom výzdobné prvky, $z$ nichž nejvíce charakteristické jsou okrouhlá ověnčená plaketa s vyobrazením Svaté Trojice v kompozičním typu Trůnu milosti (viz Bohumil 
olomoucký biskup Stanislav Thurzo) se jestě v druhé polovině 16. století nacházelo v okruhu pražských intelektuáli̊. Jeho vlastníkem byl nejprve Johannes Hynconius, který 3. června roku 1576 daroval svazek Cyprianovi Mysenusovi. ${ }^{20}$ Exemplář spolu s kalendářem na př́ideští vazby se $s$ největší pravděpodobností dostal do sbírek poznaňské univerzitní knihovny po druhé světové válce. Níže představuji návrh bibliografického popisu tohoto Almanachu.

\section{Etzlaub Erhard}

[Almanach ad annum 1527. Bohemicae]

LEtha od Narozeny Crysta pana. M.CCCCC.xxvij. Zlaty potzetb. viij. Circulum slunetznebo || xxiiij. Nedielny lytera F Rzymsky potzet. xv. [...]... Almanach mistra Erhardi Etzlaub miesstian w Nürmberku.... [Nürnberg, Hieronymus Andreae, 1526/1527], 1 fol.

Fragment (zachováno 29 řádků, 294×197 mm; kalendár pro měsíce leden, květen a záríi -16 řádků).

BCBT ani Knihopis neuvádí.

Typologicko-typografický rozbor:

Zrcadlo sazby $-282 \times 190$ [zachov.] mm. Sazba vícesloupcová, červeno-černý tisk; kalendářové značky.

Písmo - typu „Neudörfer-Andreä-Fraktur“ ve dvou velikostech:

- větší písmový stupeň: 20 r.. = $145 \mathrm{~mm}$ (viz Crous/Kirchner: opis Abb. 89, alfabvet Taf. 63, Abb. 126) - sazba řádku č. 1,12-13.

- menší písmový stupeň: 20 r̆. $=91 \mathrm{~mm}$ (Cruz/Kirchner: Opis Abb. 97, Alphabet Taft. 64, Abb. 131) - sazba řádků č. 2-11, 14-29.

NUSKA, Typologie českých renesančních vazeb In: Bohumil NUSKA (ed.), Historická knižni vazba. Sbornik príspè̃ kù k dĕjinám vazby a k metodice ochrany bistorických knižnich vazeb, 1964-1965, Liberec 1965, Tab. XVI, nr. 219) a také tři rydélka (viz B. Nuska, tamtéž, Tab. XXIV, nr. 315 - reprodukce zprava, Tab. XXV, nr. 327/1 - druhá a třetí reprodukce zprava). Dále viz Ilse SCHUNKE, Prager Buchbinder und Werkstätten in der Renaissance In: B. NUSKA (ed.), Historická knižni vazba ..., pozn. 19, s. 151-152.

20 Nekompletní provenienční vpisek dochovaný na rubu kalendáře (původně zadním př́ideští): Domino Cypriano Myseno viro docto [...] amico suo singulari scripsit Jo[bannes] Hynconius Pragae III Junii 1576. Johannes Hynconius může být identický s Janem Hynkem z Velínova, humanistou, politikem a notářem města Jihlava (žil v letech cca 1550-1623), srov. Martin HEMELỈK, Jan Hynek z Velínova (Portrét renesančního vzdèlance, ürednika, politika a båsníka), Jihlava 2015; Cyprianus Wawak Mysenus dosáh1 26.9.1571 titulu bakaláre filozofie na pražské univerzitě, srov. Liber Decanorum Facultatis Philosophicae Universitatis Pragensis, ab anno Christi 1367 usque ad annum 1585, Pars II, Monumenta Historica Universitatis Carolo-Ferdinandeae Pragensis, Tom I, Pragae 1832, s. 406. 
Text kalendáre zasazen do dekorativního dřevořezového rámu: horní heraldicko-portrétní lišta se znaky rakouských dědičných zemí (Morava, Cechy, Uhry a Slezsko) s ústředním poprsím trůnícího vládce [...] $(281 \times 49 \mathrm{~mm})$.

Levá část dekorativního rámce tvořená segmenty: sloup završený dvěma kozími hlavami, nad ním volavka a amorek s lukem a šípem. Fragment. $V$ této formě uživaná od roku 1531 B. Müllerem ve Würzburgu, srov. H. RÖTTINGER, Dürers Doppelgänger, Fig. 30 - levá lišta)

Pravá část dekorativního rámce tvořená segmenty: $\mathrm{v}$ horní části tordovaný kandelábrový sloup vztyčený na třech lvích maskách, bez maskarona na vrcholu, zbavená orámování; $22 \times 91 \mathrm{~mm}$ (v této formě uživaná od roku $1527 \mathrm{~B}$. Müllerem ve Würzburgu, srov. G. MÖNCHE, Zum Würzburger Bucbdruck, L2). V dolní časti - hlava s arabeskami, zbavená orámování; zachovaná fragmentárně ( $v$ této formě užívaná od roku 1527 B. Müllerem ve Würzburgu, srov. Mönche, Zum Würzburger Buchdruck, L1).

Poznań, Biblioteka Uniwersytecka, sign. SD 9159III. 